\title{
The Industrial Application of Water Washing Device for Aerosol Condensation in Ultra Low Flue Gas Emission
}

\author{
Lu Zhong *, Yingxin Yang, Jingling $\mathrm{Hu}$, Xiaotu Hu, Yong Liu, XueLiang Xue \\ Guangdong J-tech Environmental Technology Co., Ltd, Guangzhou, Guangdong, China
}

\begin{abstract}
The water washing device for aerosol condensation is added in the pre-cleaning tower of ammonia desulfurization device, and the basic function of the water washing device for aerosol condensation system is through the use of air/mist dual fluid spray system, atomizing the water to produce a large number of droplets, and greatly increasing the contact probability with the fine aerosol in the flue gas, and thus improving the efficiency of desulfurization and dust removal. The industrial application verifies this water washing device for aerosol condensation can effectively control the aerosol pollution from exhausts of ammonia desulphurization, and realize the ultra-low flue gas emission.
\end{abstract}

\section{Introduction}

Since 2011, fog haze weather are frequent in large area of China's beijing-tianjin-hebei region, and it has a serious impact on people's production and life and physical and mental health[1]. Fog haze mainly consists of sulfur dioxide, nitrogen oxides and inhalable particulates, and burning coal is the most fundamental cause of haze. In order to improve air quality, China has gradually increased energy conservation and emission reduction in the coal and power industry[2-3]. In 2014, the national development and reform commission, the ministry of environmental protection and the state energy administration jointly issued the action plan for coal and electricity energy conservation and emission reduction upgrading and transformation (2014-2020), in which requirements are: the atmospheric pollutants concentration in the new coal-fired power generating units in the eastern region reaches the gas turbine unit discharge limits (namely under the condition of $6 \%$ baseline oxygen content, dust, sulfur dioxide, nitrogen oxide emission concentration should be not more than 10 , $35,50 \mathrm{mg} / \mathrm{Nm}^{3}$ respectively), new units in the central region, in principle, approach or meet the emission limits of gas turbine units, and new units in western China are encouraged to approach or meet gas turbine unit emission limits. Recently, some local governments propose the project "50355" to carry out the instructions of the state that strict abatement of haze which is higher than the national air emission standard, namely NOx is less than $50 \mathrm{mg} / \mathrm{Nm}^{3}, \mathrm{SO}_{2}$ is less than $35 \mathrm{mg} / \mathrm{Nm}^{3}$, and smoke is less than $5 \mathrm{mg} / \mathrm{Nm}^{3}$. In order to meet the increasingly strict environmental emission standards, it is imperative to upgrade the existing coal-fired power plants with ultra-low emission technology[4-6].

There are two main sources of soot from coal-fired boilers: one is residual amount of smoke and dust from coal combustion after passing through electrostaic precipitator, the other is the residual amount of desulfurization products carried by flue gas in the desulfurization tower spray slurry adopting wet desulfurization technology for desulfurization treatment, which is also an important cause of desulfurization plume trailing tail and "chimney rain"[7-8].

The desulfurization tower was optimized by adding the water washing device for aerosol condensation on the basis of traditional ammonia desulfurization and dust removal technology. By using air mist dual fluid spray system, water is atomized to produce a large number of droplets, which greatly increase the contact probability with the fine aerosol in the flue gas, so that it can control the aerosol pollution at the end of flue gas ammonia desulfurization, reduce emission targets of smoke, and solve the technical problems of meeting standards and even ultra-low emissions effectively.

\section{Technology principles}

The basic function of the water washing device for aerosol condensation is adopting the air/mist dual fluid spray system to atomize water to produce large amount of droplets and increase the contact probability dramatically with fine aerosols in the flue gas. The function mechanism is: (1)through heat and mass transfer between atomized water and the flue gas, the flue gas temperature is further lowered, and thus the water vapor and remained aerosols in the flue gas coagulate on water droplets and enlarge the droplets to further increase the demist effeciency, which is proved by long-term practice; (2)water atomization increases collision frequency with aerosols and leads to coagulation to make small particulater larger which can

\footnotetext{
* Corresponding author: zhongl@gdj-tech.com
} 


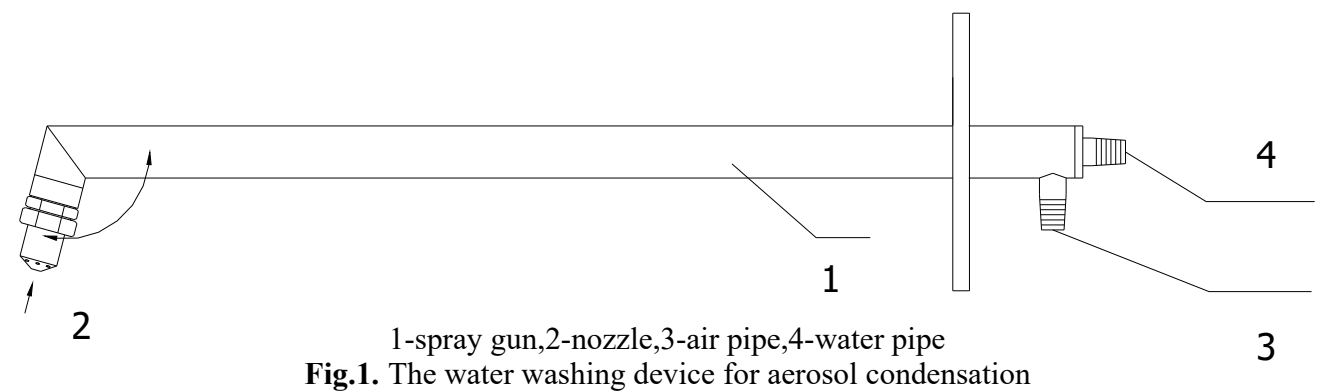

be readily removed in the electrostaic precipitator later in the process.

The water in the aerosol spray system tank is adjusted to certain pressure and flow by water pump after being filtered, and then delivered through pipe line to the spray gun, and then be atomized under compressed air to procude very fine atomized particulater, and ammonium salt aerosols are fused in the droplets to increase the partical sized of aerosol particulaters and decrease the dispersity of aerosols. These water mists can be collected and removed effeciently by electrostaic precipitator later in the process. The gas atomization spray system in this program includes aerosol spray system, water spray system and related pump station system, group valve system and control system.

\section{Technical features}

The newly added water washing device for aerosol condensation system facilitates absorption, coagulation and enlargement of fine aerosols, and can improve removal ability of the electrostaic precipitator later in the process, and it is an advanced treatment of the flue gas.

(1) Adopting spray gun atomization technique can increase the heat and mass transfer with the flue gas, and can cool the flue gas rapidly, enabling the recycle spray of the prewashing tower to operate in relatively lower tempreture to minimized the volatilization of ammonium sulfite and generation of aerosols.

(2) Atomizing water can increase the specific surface and collision frequency with aerosol particulaters, leading to coagulation which makes remaining fine particles into larger particles, and then removed efficiently in the electrostaic precipitator later in the process.

(3) Comparing with spray layer, it has smaller spray flow, better dispersity, energy saving and apt to the control of aggregative indicators.

\section{Mechnical configuration}

The water washing device for aerosol condensation system mainly includes spray gun, water pipe system, gas line system, filtration unit, water pump unit, flow detection unit and steel base plate support. The average partical size of the mist spray is $60 \mu \mathrm{m}$, and the largest is $140 \mu \mathrm{m}$. The initial maximum speed of spray mist particles is $30-40 \mathrm{~m} / \mathrm{s}$. The system can decrease the inlet flue gas temperature by $10-20^{\circ} \mathrm{C}$.

\section{Project case}

In order to meet improving environmental requirements, flue gas desulfurization of 1-4\# boilers in Baling Petrochemical Corp Power Division are all adopted the J-TECH ammonia desulfurization ultra low emission technology which includes the water washing device for aerosol condensation system that is developed by our company.

\subsection{Retrofit scheme}

The flue gas desulfurization of $1 \#$ boiler is retrofited by the ultra low emission ammonia desulfurization technology, which includes aerosol coagulation, three layers spray in prewashing tower, two layers spray in absorption tower, cyclone demist, two layers water spray and the electrostaic precipitor. The tehcnological process is as shown in Fig.2. The flow of the water washing device for aerosol condensation is $5 \mathrm{~m}^{3} / \mathrm{h}$. The flue gas enter the prewashing tower after being dedusted, and the water washing device for aerosol condensation can rapidly decrease flue gas temperature by $10 \sim 20^{\circ} \mathrm{C}$, which can increase desulfurization effeciency and decrease the generation of aerosols.

\subsection{Operation effect}

The desulfurization device of $1 \#$ boiler in Baling Petrochemical Corp has completed ultra clean emission retrofit in September 2016, in which water washing device for aerosol condensation system is adopted. And the operation of the system has been stable since it is put into use. The main performance parameters and third party monitoring results are as shown in Table 1 . The third party monitoring results show that the average concentration of $\mathrm{SO}_{2}$ in the outlet flue gas is $9.2 \mathrm{mg} / \mathrm{Nm}^{3}$ and the average concentration of smoke is $1.8 \mathrm{mg} / \mathrm{Nm}^{3}$. This retrofit can effectively control the emission of aerosols and perfectly reach the design technical requirements and the state emission standards, and fulful the goal of concentration of $\mathrm{SO}_{2}$ in the outlet flue gas should be no higher than $35 \mathrm{mg} / \mathrm{Nm}^{3}$ and the concentration of smoke should be no higher than $5 \mathrm{mg} / \mathrm{Nm}^{3}$, and realize ultra clean emission of flue gas. 
This retrofit has adopted ammonia desulfurization device with water washing device for aerosol condensation, which is better and more energy saving

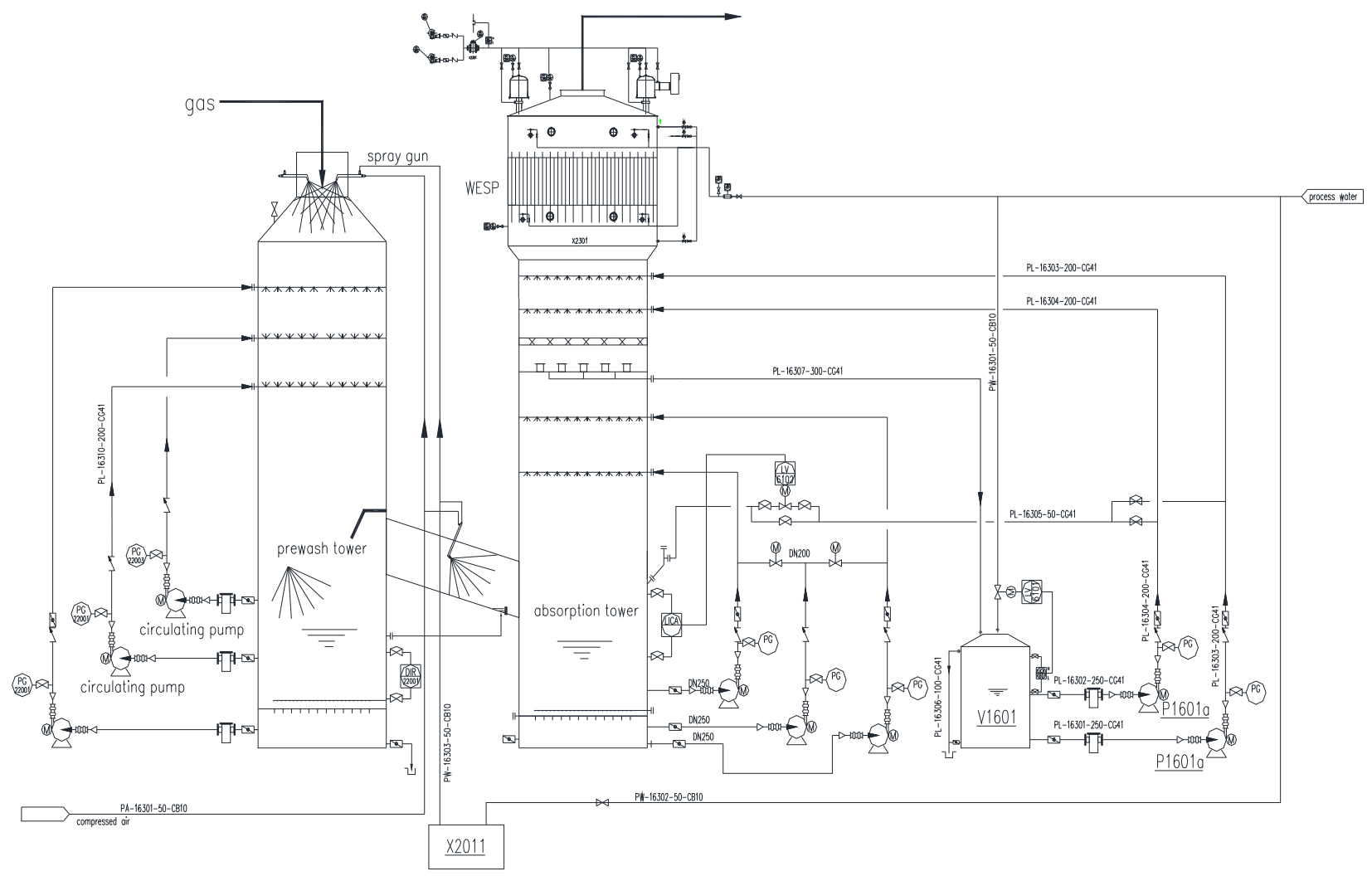

Fig .2. Process flow diagram of flue gas desulfurization

than just adding one more layer of spraying in the prewashing tower. Newly added water washing device for aerosol condensation system can facilitate the absorption, coagulation, enlargement of the fine aerosols, and improve removal effeciency of the electrostaic precipitator later in the process, which is the advanced treatment for the flue gas.

Table 1. Main performance index of electrostatic precipitator before and after modification.

\begin{tabular}{|c|c|c|c|}
\hline $\begin{array}{c}\text { Performance } \\
\text { indicators }\end{array}$ & $\begin{array}{c}\text { Before } \\
\text { modificat } \\
\text { ion }\end{array}$ & $\begin{array}{c}\text { design } \\
\text { requirem } \\
\text { ents }\end{array}$ & $\begin{array}{c}\text { after } \\
\text { modificat } \\
\text { ion }\end{array}$ \\
\hline $\begin{array}{c}\text { Standard smoke } \\
\text { volume } /\left(\mathrm{Nm}^{3} / \mathrm{h}\right)\end{array}$ & $\begin{array}{c}230000- \\
270000\end{array}$ & 270000 & $\begin{array}{c}230000- \\
270000\end{array}$ \\
\hline $\begin{array}{c}\text { Concentration of } \\
\text { input } \mathrm{SO}_{2} / \\
\left(\mathrm{mg} / \mathrm{Nm}^{3}\right)\end{array}$ & $\leq 100$ & $\leq 35$ & 9.2 \\
\hline $\begin{array}{c}\text { Temperature of } \\
\left.\text { output flue gas } /{ }^{\circ} \mathrm{C}\right)\end{array}$ & $50 \pm 3$ & $50 \pm 3$ & $47-50$ \\
\hline $\begin{array}{c}\text { Concentration of } \\
\text { output smoke } \\
/\left(\mathrm{mg} / \mathrm{Nm}^{3}\right)\end{array}$ & 80 & $\leq 10$ & 1.8 \\
\hline
\end{tabular}

\begin{tabular}{|c|c|c|c|}
\hline $\begin{array}{c}\text { Concentration of } \\
\text { output ammonia } \\
/\left(\mathrm{mg} / \mathrm{Nm}^{3}\right)\end{array}$ & $\leq 8$ & $\leq 8$ & $\leq 8$ \\
\hline
\end{tabular}

\section{Conclusion}

The water washing device for aerosol condensation can significantly improve the dedust effeciency, effectively control the aerosol pollution at the end of the flue gas ammonia desulfurization, and facilitate absorption, coagulation and enlargement of fine aerosols, which can enhance dedust capacity of the electrostaic precipitator later in the process, and reach the ultra clean emission standard that smoke concentration is lower than 5 $\mathrm{mg} / \mathrm{Nm}^{3}$, realizing ultra clean emission of the flue gas.

\section{Acknowledgements}

The authors gratefully acknowledge financial support by Science and Technology Plan Project of Guangdong Province, China (No. 2017B090901057).

\section{References}

1. Z. Hu, L. Li, J. Xu, Electric Power Science and Engineering, 32, 70 (2016) 
2. X. Hu, Environmental Engineering, 2, 80 (2015)

3. H. White, Industrial Dust Collection (1984)

4. Y. Ren, C. Kong, J. Liu, W. Zhang, B. Luo, Electric Power, 49, 181 (2016)

5. J. Hao, K. He, H. Zhao, H. Zhang, R. Guo, Acta Scientiae Circumstantiae, 8, 480 (1988)

6. J. Li, S. Li, Chinese Journal of Environmental Engineering, 5, 399 (2011)

7. K. Wang, L. Yin, Y. Xu, X. Liu, Environment and Sustainable Development, 6, 149 (2015)

8. H. Liu, Industrial Safety and Environmental Protection, 42, 20 (2016) 